\title{
Launching the Latin American Epidemiological Cooperation relating to Noncommunicable Diseases
}

\author{
Paulo Andrade Lotufo' \\ Faculdade de Medicina da Universidade de São Paulo (FMUSP), São Paulo (SP), Brazil
}

'MD, DrPH. Full Professor, Department of Internal Medicine, Faculdade de Medicina da Universidade de São Paulo (FMUSP), São Paulo (SP), Brazil.

(Dorcid.org/0000-0002-4856-8450
Latin America and the Caribbean form one of the world's macroregions and comprise 50 independent countries and a few colonies, with a total of approximately 650 million inhabitants. Although these countries have almost twice the population of the United States, the combined gross national product of Latin American and Caribbean countries is only $55 \%$ of that of the United States. ${ }^{1}$ The socioeconomic differences between Latin American and Caribbean countries and the United States are reflected in educational, health-related and scientific indexes that show Latin American and Caribbean countries unfavorably. The amount of money spent on medical care and, especially, to support medical and health-related research in the United States is immensely greater than in Latin American and Caribbean countries. In contrast, the principle of universal health care coverage that has been adopted in most Latin American and Caribbean countries faces stiff opposition in the United States. ${ }^{2}$

Despite these differences, the epidemiological profile of all countries in the Americas is much closer than what was seen half a century ago. Infectious and parasitic diseases in Latin America have declined with only a few exceptions, such as arbovirus-borne diseases. Likewise, disorders relating to undernutrition and maternal care have faded away in most Latin American and Caribbean countries. Noncommunicable diseases such as cardiovascular, respiratory, renal, mental and osteoarticular diseases have become the most important cause of death, morbidity and disability on both sides of the border between the United States and Latin American and Caribbean countries. ${ }^{3}$ One example of this is the astonishingly temporal trends of obesity prevalence observed between Latin American and Caribbean countries and the United States. ${ }^{4}$ The epidemiological profile and priorities in Latin American and Caribbean countries were discussed previously on this page, in an analysis on Argentina, Brazil, Colombia and Mexico, using data from the Global Burden of Diseases study. Briefly, the priorities for noncommunicable diseases have been determined to be: (1) control of alcohol intake; (2) detection, treatment and control of hypertension; (3) prevention of stroke and coronary heart disease secondary care; (4) prevention of obesity and diabetes; and (5) screening for chronic kidney disease. ${ }^{5}$

To face the challenge of noncommunicable diseases, strong scientific support from epidemiological studies has been necessary. Despite the enormous contribution of the United States towards the epidemiology of chronic diseases, such as through the seminal Framingham Heart Study, ${ }^{6}$ and the contributions made by other countries, the realities of Latin American and Caribbean countries impose a specific approach. Specific longitudinal studies addressing particular issues relating to ethnicity, diet and socioeconomic determinants are needed. Fortunately, the challenge of understanding the determinants of chronic diseases in Latin American and Caribbean countries has indisputably been addressed by local scientists and public health authorities in Argentina, ${ }^{7}$ Brazil, ${ }^{8}$ Chile,,${ }^{79}$ Mexico, ${ }^{10}$ Peru ${ }^{11}$ and Uruguay. ${ }^{7}$

In April 2018, it was possible to organize an initial summit event in Chile, which was called the "First Meeting on Latin American Population-Based Cohorts for Studies on Chronic Diseases" (I Jornada de Cohortes Poblacionales Latinoamericana para el Estudio de Enfermedades Crónicas, COPLAS). This meeting brought together researchers from 12 studies. Table 1 describes the five ongoing cohort studies in Latin American and Caribbean countries among adults without any specific disease. ${ }^{7-11}$ 
This meeting marked a big step forward for Latin American and Caribbean investigators working on the epidemiology of noncommunicable diseases, towards permanent cooperation. In the near future, this should include more studies in those nations and in other countries. The consequences of this aggregation will allow Latin American and Caribbean epidemiological scientists to carve out a role as significant players worldwide, in issues relating to noncommunicable diseases.

\section{REFERENCES}

1. United Nations Statistics Division - National Accounts". Available from: https://unstats.un.org/unsd/snaama/Introduction.asp. Accessed in 2018 (May 30).

2. Both in rich and poor countries, universal health care brings huge benefits. The Economist, April 28, 2018. Available from: https://www.economist. com/news/special-report/21740873-argument-universal-health-careclear-getting-there-difficult-says-john. Accessed in 2018 (May 21).

3. GBD 2016 Causes of Death Collaborators. Global, regional, and national age-sex specific mortality for 264 causes of death, 1980-2016: a systematic analysis for the Global Burden of Disease Study 2016. Lancet. 2017;390(10100):1151-1210. PMID: 28919116; doi: 10.1016/ S0140-6736(17)32152-9.
4. NCD Risk Factor Collaboration (NCD-RisC). Worldwide trends in bodymass index, underweight, overweight, and obesity from 1975 to 2016: a pooled analysis of 2416 population-based measurement studies in 128.9 million children, adolescents, and adults. Lancet. 2017;390(10113):262742. PMID: 29029897; doi: 10.1016/S0140-6736(17)32129-3.

5. Lotufo PA. Knowing for whom the bell tolls: acting locally and thinking globally. Brazil, Latin America and the Global Burden of Diseases, 2015. Sao Paulo Med J. 2016;134(6):469-72. PMID: 28076628; doi: 10.1590/1516-3180.2016.1346171016.

6. Tsao CW, Vasan RS. Cohort Profile: The Framingham Heart Study (FHS): overview of milestones in cardiovascular epidemiology. Int J Epidemiol. 2015;44(6):1800-13. PMID: 26705418; doi: 10.1093/ije/dyv337.

7. Rubinstein AL, Irazola VE, Poggio R, et al. Detection and follow-up of cardiovascular disease and risk factors in the Southern Cone of Latin America: the CESCAS I study. BMJ Open. 2011;1(1):e000126. PMID: 22021769; doi: 10.1136/bmjopen-2011-000126.

8. Aquino EM, Barreto SM, Bensenor IM, et al. Brazilian Longitudinal Study of Adult Health (ELSA-Brasil): objectives and design. Am J Epidemiol. 2012;175(4):315-24. PMID: 22234482; doi: 10.1093/aje/kwr294

9. Ferreccio C, Roa JC, Bambs C, et al. Study protocol for the Maule Cohort (MAUCO) of chronic diseases, Chile 2014-2024. BMC Public Health. 2016;16:122. PMID: 26847446; doi: 10.1186/s12889-015-2454-2.

Table 1. Description of five ongoing Latin American cohorts among adults, addressing cardiovascular diseases (CVDs), cancer, diabetes and chronic pulmonary obstructive disease (COPD)

\begin{tabular}{|c|c|c|c|c|c|c|}
\hline $\begin{array}{l}\text { Acronym } \\
\text { (reference) }\end{array}$ & Name & Country & Main aim & $\begin{array}{l}\text { Number of } \\
\text { participants }\end{array}$ & Start date & Website \\
\hline CESCAS $^{7}$ & $\begin{array}{l}\text { Center for } \\
\text { Excellence in } \\
\text { Cardiovascular } \\
\text { Health in South } \\
\text { America }\end{array}$ & $\begin{array}{l}\text { Argentina, } \\
\text { Chile and } \\
\text { Uruguay }\end{array}$ & $\begin{array}{c}\text { Prevalence, incidence } \\
\text { and distribution of risk } \\
\text { factors for CVDs, COPD } \\
\text { and cancer }\end{array}$ & $\begin{array}{c}7,524 \text { adults in } 4 \text { cities } \\
\text { in } 3 \text { countries aged } 35 \\
\text { to } 74 \text { years } \\
\text { Random sampling }\end{array}$ & 2010 & https://estudiocescas.iecs.org.ar/ \\
\hline ELSA-Brasil ${ }^{8}$ & $\begin{array}{l}\text { Brazilian } \\
\text { Longitudinal Study } \\
\text { of Adult Health }\end{array}$ & Brazil & $\begin{array}{l}\text { Development and } \\
\text { progression of clinical } \\
\text { and subclinical chronic } \\
\text { diseases, particularly } \\
\text { CVDs and diabetes. }\end{array}$ & $\begin{array}{l}15,105 \text { civil servants } \\
\text { aged } 35-74 \text { years in } 6 \\
\text { cities in Brazil }\end{array}$ & 2008 & http://www.elsa.org.br/ \\
\hline MAUCO/ACCDIS 9 & $\begin{array}{c}\text { Maule Cohort/ } \\
\text { Advanced Center } \\
\text { for Chronic Diseases }\end{array}$ & Chile & $\begin{array}{l}\text { Factors involved in } \\
\text { development of or } \\
\text { protection against } \\
\text { CVDs, cancer, diabetes }\end{array}$ & $\begin{array}{l}10,000 \text { unselected } \\
\text { adults aged } 38 \text { to } \\
74 \text { years from the } \\
\text { agricultural town } \\
\text { of Molina }\end{array}$ & 2014 & http://www.accdis.cl \\
\hline Cronicas $^{11}$ & $\begin{array}{l}\text { Centro de Excelencia } \\
\text { en Enfermedades } \\
\text { Cronicas, Universidad } \\
\text { Cayetano Heredia }\end{array}$ & Peru & $\begin{array}{l}\text { Role of geographical } \\
\text { and environmental } \\
\text { variation as risk factors } \\
\text { for chronic disease } \\
\text { (CVDs and COPD) }\end{array}$ & $\begin{array}{l}3000 \text { individuals, } 35 \\
\text { years of age or older, } \\
\text { from } 4 \text { regions in Peru: } \\
\text { Tumbes, Puno (urban), } \\
\text { Puno (rural), and Lima }\end{array}$ & 2010 & http://www.cronicas-upch.pe/ \\
\hline
\end{tabular}


10. Lajous M, Ortiz-Panozo E, Monge AL, et al. Cohort Profile:The Mexican Teachers'Cohort (MTC). Int J Epidemiol. 2017;46(2):e10. PMID: 26337903; doi: 10.1093/ije/dyv123.

11. Miranda JJ, Bernabe-Ortiz A, Smeeth L, et al. Addressing geographical variation in the progression of non-communicable diseases in Peru: the CRONICAS cohort study protocol. BMJ Open. 2012;2(1):e000610. PMID: 22240652; doi: 10.1136/bmjopen-2011-000610.

Acknowledgement: the author is indebted to all 2018 COPLAS meeting participants, especially the chair, Catterina Ferrecio. Gabriella Repetto organized Table 1

Sources of funding: Not declared

Conflict of interest: Not declared

Address for correspondence:

Centro de Pesquisa Clínica e Epidemiologia, Hospital Universitário (HU), Universidade de São Paulo (USP)

Av. Prof. Lineu Prestes, 2.565

Butantã — São Paulo (SP) — Brasil

Tel. (+55 11) 3091-9300

E-mail: palotufo@usp.br 